\title{
Generosity Maxim in Leech's Theory in Pshdar Area: Socio- Pragmatic Perspective
}

\section{Ibrahim Mahmood Ibrahim}

English Department, College of Basic Education, University of Salahaddin, Erbil, Kurdistan Region, Iraq.

E-mail: imirbr1@gmail.com

\section{Salam Nawkhosh Bakir}

English Department, College of Basic Education, University of Salahaddin, Erbil, Kurdistan Region, Iraq.

E-mail: salam.bakir@su.edu.krd

\section{Abstract:}

This paper is entitled 'Generosity Maxim in Leech's Theory in Pshdar Area: SocioPragmatic Perspective, which aims at showing generosity among individuals including showing generosity in this specific area for the purpose of finding out its roots people, because generosity maxim is minimizing self to others, and indicating such factors as religion, education, non-education, and gender affect the utterance. The principles of politeness which have been recognized by Leech are the Maxim of Tact, the Maxim of Generosity, the Maxim of Modesty, the Maxim of approbation, the Maxim of Agreement, and the Maxim of Sympathy. It is important to bear in mind that this theory focuses on individual face, there are various face threatening acts, for instance the threat can be assumed to the hearer or to the speaker.

This paper conducts a survey of Pshdaryan district through using a questionnaire as a quantitative method for the purpose of data collection. The participants of this study are the people of Pshdar area who are 162 participants from different classes, genders, educational background, age, and occupation.

The result of the study showed that generosity is the main reason behind using both direct and indirect offers and invitations. Besides, it showed that the cost-benefit scale can explain the politeness utterance raised in performing these speech acts Finally, it is recommended that other politeness principle maxims are tested in Kurdish culture to know the level of the maxims practically.

Keywords: Generosity, Politeness, Sociopragmatics, Pragmatics, Social Distance. 


\section{Introduction :}

Generosity in the Pshdar area can be investigated through a questionnaire tool that is considered as an important aspect of negative and positive faces. Leech argues that politeness is accounted for as a tact maxim which is principled in a pragmatic field; therefore, to be a polite person, Leech postulates six maxims, which are used by people to express their beliefs either favourable or unfavourable on the whole. With regard to politeness, the speaker implies unfavourable beliefs which are impolite ones by the speaker to the addressee. On the other hand, favourable beliefs are polite by the speaker to the hearer (Leech 2014).

Similarly, politeness from the view of Brown and Levinsons' theory is considered to be social behaviour of individuals in society through face. However, face is accounted as a publicimage or self-image of individuals. Moreover, politeness is determined in different strategic aspects by four orientations which are on-record, off record, and they become negative politeness or positive politeness that leads to face saving and face loss (Brown \& Levinson, 1987, pp. 19-38).

This study is an attempt to find out to what extent that Pshdaryan people are generous? To what extent does the correlation between individuals of the Pshdar Area exist? Does the generosity maxim imply in this limited area?

The aim of this study is to show generosity among individuals of the Pshdar area. Nevertheless, finding out the correlation between people of which type of people are more generous, and then finding out the concept of generosity maxim among individuals of Kurdish people. The data collection tool of the study is a questionnaire which has been carried out to the generosity maxim in the theory of politeness by Geoffrey Leech. It has been hypothesized that religion has an effect on individuals. Moreover, financial status as a social value also has a role offering and invitation of the utterances. In addition to the basic norms of politeness which are social distances (D), relative power $(\mathrm{P})$, and ranking imposition $(\mathrm{R})$ have main roles in politeness. Nevertheless, among social values neither social classes, nor occupation had effectively the enactment of generosity. It is noted that Kurdish people are known for hospitality and generosity. Females are more generous than males.

The procedures of the study begin with the introduction and some pragmatic notions which are related to the topic, typically Leech's maxim of generosity in the theory of politeness is explained to investigate the items of the questionnaire which consist of (10) items. The tool which is used for the data collection is a questionnaire which is distributed to 162 participants, and then the collected data has been entered into the updated version 20 of SPSS program and analysed. 
The scope of this study is limited to the generosity maxim by Pshdaryan.

The participants of this study are the people of Pshdar area including different classes, genders, age, and occupation.. The significance of this study is to be of value to those who work in socio-pragmatics, and discourse analysis with regards to politeness among Kurdish people.

\section{Theoretical Background}

In this research, such pragmatic notions as sociopragmatic, sociopragmatic failure, pragmalinguistic, politeness, discourse, face, face saving and face loss, pragmatic behaviour and some articles related to the topic have been reviewed as follows;

A study which is entitled" Generosity Reward is a Happier You" by Tobler from the university of Zurich's laboratory for Neutral System and social science, the problem of this study deals with why do many people are happier than others? The data collection of the study is focus group, which has been used through functional (MRI) (henceforth; Magnetic Resonance Imaging) brain scanning discovered among a group of people to understand the reactions of simultaneously working brains. It can be stated that when someone acts generously with others, it has found about that the giver is happier than the taker, as compared to giving for others rather than for themselves; therefore, the brain of a giver, the function of (MRI), and the happiness region, which is scientifically called central stratum associated with making decision cortex of the orbitofrontal both of them are in charge of generosity and socializing human's activity process increased. This study differs from the current study in method which is focus grouping, and the procedures have been done in a scientific laboratory (Tobler, 2020).

Another study which is conducted in entitle "Interpersonal distance adjustments after interactions with a generous selfish trustee during a repeated trust game" Lisa et al (2020), which mainly refers to social behaviour undertaking social distance of individuals according to this study. It is worth mentioning that the researchers are from the University of Vienna, Austria, psychology's faculty, Biopsychology and Neuropsychopharmacology Unit, Department of Basic Research Methods and Psychological Research, plus Affective Neuroscience and social Cognitive Unit and Royal Holloway, London University, United Kingdom Department of economics Laboratory of Experimental Economics. The data collection of this study is an experimental focus group, which is between two groups male and female, and different ages. The problem of this study is development of interactional behaviour between participants in a dictator game to show that the level of generosity between interpersonal distance. Consequently, the distance affects the generosity acting among informants and on what decision-making passes among participants based on the relationship between interpersonal distances in the game. It is noted that this study differs from this current study in methodology, which is an experimental focus group, and the participants are gamers 
Lakoff briefs her theory in three principles of politeness which are "Make A feel good -be friendly" , "Don't impose "'and "Give option", besides her rules determine " Distance", “ Camaraderie" and "Deference" ; as Eelen (2001) described Lakoff is the mother of modern politeness theory (Lakoff, 1973).

\subsection{Sociopragmatics}

Some social norms are sometimes quietly normal for the language user, although it does not mean these norms are at ease for other cultures. Individual language use under the influences of several reasons which are vertically and horizontally behind the scenes of transaction on sociocultural weightiness in society, namely politeness evaluation, such as social values instantiation gender, age, and social classes. These weights potentially have an impact on showing politeness factors of sociocultural. As someone wants to be generous by issuing an invitation, or offering something, which is considered in the tact maxim in politeness sociopragmatically non-linguistic channels are more significant rather than uttering actual words, impressively (Leech 2014).

\subsubsection{Sociopragmatic Failure}

In any language usage, there are some linguistic behaviour which are considered to be polite in many cultures, although they are not polite to other societies, this circumstance is called pragmatic failure. It totally relates to cultural norms in any community (Allan, et al 2012).

Pragmatic failure can be noted as three different failure categories, sociopragmatic failure, pragmalinguistic failure and faulty assessment by participants' competence, background knowledge and intentions. Sociopragmatic failure happens between individuals by the context of utterance is assessed divergently in any social aspect. For example, in some places in the north of England female and male use the word love with the customers, there might be personal offense while entering a customer is said " Morning, luv, what can I do for you" for many cross-cultures the word love may be rude or insulting at that moment (LoCastro 2012).

\subsubsection{Pragmalinguistic}

To mitigate the face threatening acts, the speaker manages to add some intensifiers to the context according to the necessity of the circumstance.

Leech (2014) explains pragmalinguistics relates to pragmaticalization of lexicogramticalization of a linguistic phenomenon, which deals with the grammatical points of social phenomenon in a community, for example, the auxiliary verb of 'can' and 'could' have 
two different features namely, form in principle, and consultants to the addressee in accordance with Leech's theory. These modal verbs can and could pragmalinguistically transfer in their meaning politeness phenomenon in which they have been grammatically interpreted as a request or a reject complying with to the addressee in a context-free function and form which is called realization. There is another factor to keep in mind, which is the directness of imposition in degree and frequency of pragmalinguistics, considering conventionalization or in idiomaticization, however, the use of 'could' in a context has neg-politeness formula semantically mitigating apparently the imposition on the addressee.

Precisely, in any utterance, which is out of a context on the basis of meaning is called relatively pragmalinguistic politeness, although pragmalinguistics is formerly absolute.

a- Make it two, please.

b- Could I ask you to make it two, please?

c- I wonder if I could just ask you to make it two, please.

It can be noted that the first utterance, which is (a) is impolite, because it is totally imposition on the hearer, while the second one, which is (b) is more polite than (a); but the third one, which is (c) is more polite than (b), because in each of the utterance a semantic intensifier has been added to them.

(Grundy, 2008, cited in Leech 1983, p.11) "pragmalinguistics is a type of pragmatic knowledge, in a way to mitigate formula that people have got knowledge natively, for instance particular illocutions are conveyed through providing language."

In this case study that has been observed Pshdaryan people never dislike guests; therefore they are always happy with guests, and this characteristic makes those people to appear very generous with strangers and even with each other, that is to say, no foreigners feel loneliness with the Pshdaryan Rasul (2018).

Specifically, most of the well-known tribes which still exist in Pshdar area, and they have got such nice characteristics as hospitality, warmly welcoming strange people and inviting others, keeping those people who are homeless are reflected in their daily language usage. For example, one of the most well-known tribes in this specific area is Mirawdeli and other tribes that act generously. Nevertheless, they feed everyone without separating rationality, and they also help those who are in need for good deeds, therefore, this aspect of the Pshdaryan characteristic generation to generation remains from their ancestors cognitively, the town did not have restaurants or hotels to stay strangers in, because guests and visitors to the town were being taken to their Pshdaryans' house to be served well. 
They emphasize the following utterances with others to show generosity.
A. You, will be my guest for dinner.
A بوّ نيوه رِوّيه ميوانى منى. A
B. You must be my guest for dinner.
-B دهبيت بوّ نيوهرِيه هـهر ميوانى من بى.
C. I would like to be my guest for dinner.

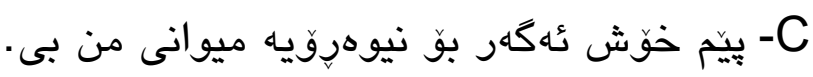

In a real situation, (b) is more practical than (a) and (c), though (c) is politer than (a), and (b), because the speaker imposes himself and benefits others, and in each of the above utterances a semantic intensifier has been added to them (Rasul 2018).

\subsection{Virtue of Humanity}

The virtue of generosity, which reflects pragmatically in language performance among individuals by choosing elements of language consequently, generosity makes people happy by maximizing others and minimizing self, as appeared in politeness maxims (Froding. 2013).

Generosity virtue comes from habituation and education. That is to say, generosity has emotionality and cognitive dimensions since knowledge is qualified in the sense of people's language usage (ibíd.)

\section{.2.3 Face}

As individuals hold a face in a community, the deviations occur among people in accordance with situations. For example ''Face is a self-image in general, interactants have an inevitable trait existentially, which enters into action by a virtue is called face" (BargielaChiappini \& Kadar, 2011, p.31).

(Bargiela-Chiappini, et al. 2011) argue that face is the value of society. Besides, face from the perspectives of sociopragmatics focusing bald on record utterances, such as order, command which fall into the face in language usage, nevertheless many people bulge in addressing interpersonal pragmatics. In other words, a face represents a society on loan.

Face as public-image has been sharply criticized, through directives, indirectives, and conventionally, non-conventionally because it is the lynchpin in the community according to Brown and Levinsons' model in the way that speech acts present (Ibid). 


\subsubsection{Face-Saving in Politeness}

As it is known that people hold face, this face may mitigate utterance with others or impede it. (Geyer, 2008, cited Brown and Levinson, 1987) points out that face as a public image, which everyone holds a face in a community meanwhile having reasons generally in society, deviations most probably occur. It is important to know that face mainly depends on what someone's face wants of others. In addition to that face in politeness theory can be noted as a positive, which sometimes is approved or appreciated by others, therefore the self-image reflects in the interactants crucially involving desires. On the other hand, other's faces ought to interpersonally maintain communication such as face-threatening acts might happen between speakers and hearers. In other words, face sometimes can be accounted as a negative face which face wants freedom of action and imposition in the territory of interpersonal preservation i.e. interlocutors need to have a strategy to act politely which is called politeness strategies. Generally, these strategies aim to reduce face-threatening acts in the case of Bald On-record strategy which is the least offense of politeness, and the most serious strategy of politeness is off-record. Under these circumstances, these strategies are notably dependent on social distance, social power and ranking imposition among individuals in the communities while interacting. The speaker mitigates formulae speech acts with the addressee.

\subsubsection{Face-losing in Politeness}

Unimpeded utterances by face in a community making harm for people, therefore, in facelosing, the interlocutor relies on the weightiness of other faces, which are known as D, P, R (henceforth: Social Distance, Social Power, and Ranking imposition). By the way the interlocutor focuses on the weightiness of the dietary relation among individuals in any utterance (Geyer, 2008).

Losing face can be noted through possible engagement among people in different social situations. In different circumstances losing face happens among people with regard to different social ranking and social position for example among family members going bald on record is not such as outside of the family members; if someone in the family member says " pass me the salt" in this situation the utterance is quite normal regarding to social ranking and position, meanwhile the utterance refers to face threatening acts, too. Moreover, it is not compared to someone in a restaurant uttered the previous Bald on record to someone else. For example: someone utters "Get lost" or "Forget it" in these bald on record speech acts face-losing easily is noted (Mey, 2001).

According to Watt (2003) there is a significant point in face-losing and face-saving acts which is the distance between the speaker and the addressee. Consequently, everything in utterance belongs to the social distance either to the speaker or to the hearer. 


\subsection{Discourse}

Text and context need to be analyzed in situations in which they should be easily understood in general across the statement, as Crystal (2007) argues discourse is a new style of the study language which focuses on the natural occurring structure spoken language in which appears in such speech acts as conversations, commentaries, interviews; therefore, analysing sentences leads to producing coherent sense. (Reimer 2010, p.304-8 cited Hopper and Thompson, 1984) states that discourse is only grammatical elements in the text and context only in functioning in the linguistic field. Brown et al, (2010, P.173-74) "argue while language is used a performance is acted, then a behaviour has borne as a result of performing. Besides discourse is not all meanings, however there are markers which relate to discourse such as grammatical markers, pragmatic markers, etc.'”

Yule (1996) argues that discourse analysis is an attempt to discover for what is unsaid in the interactions of social communication. Moreover, pragmatics aims at paying more attention firstly, in conversation, secondly in psychological concerns, and beliefs, thirdly, in expectations, and background knowledge. Nevertheless, specifically the most common functions of pragmatics is to explore what is in mind between the hearer and the speaker inevitably.

\section{4 pragmatic behaviour}

"In Great Britain children are taught some pragmatic communicative behaviour at the early childhood time so this behaviour pragmatically becomes part of life of English people. For one thing, children have been taught to use the word " please" which is glorifying word and costbenefit to the speaker, while asking something from others to self, which becomes minimizing from other to self, and they have taught using the utterance "thank you" in response to have something, either getting it or giving it back. Consequently, these pragmatic distinctions refer to formality, politeness and intimacy of people while cooperating with each other, thus social class, social status reflect in politeness respecting several language use picked up by people. However, cultures have different styles of politeness perspective language use in one point all collected which is being respectful for others by any way" (Crystal, 2007, pp. 275-85).

\section{Methodology of Data Collection}

\subsection{Introduction}

The summary of this study presents in this section which the research methodology is involving the procedures that have been conducted for the purpose of the data collection which is named a questionnaire. The questionnaire, pilot test, and face validity have been used for the data collection of the research.

It is important to be in mind that the researcher relies mainly on this current study which is the maxim of Generosity in the theory of politeness, by Leech (1983). 


\subsection{Sample and Participants}

Pshdaryan people are the samples of the participants who have been taken randomly; the researcher used social values, namely gender, educational background, marital status, social classes, economic status, and occupation. These social values helped the researcher to know the effectiveness of their language performances through using the notion of generosity as one of the maxim of politeness among individuals of this limited area.

\subsection{Data Collection Tools}

Firstly, a questionnaire as a tool has been implemented for the purpose of investigating individuals' pragmatic competence of the Pshdar area.

Secondly, a quantitative method adopted as an approach in a form with a consent form that the researcher presented to the participants.

\subsection{Questionnaire}

LoCastro (2012) states in pragmatics language discourse nowadays is a famous research method through using a questionnaire tool to do a research, that is why a questionnaire as a primary tool used in this current study; therefore ten items in a form were used in the study and the participants have the chance to choose one of the five scales.

\subsection{Pilot Test}

The researcher has conducted a pilot test to investigate the accuracy of the items in a questionnaire. Specifically, the researcher tested items by choosing some people randomly concerning a sociopragmatic perspective from Pshdaryan people to understand the effectiveness of the tool in practice; as a result the items of the questionnaire assured the researcher to carry out the study. According to Walsh (2001) "pilot test reveals all the feeble of the items in any study." Similarly, Abbas (cited in Robson, 2012) the methods used for the data collection assures the exact and suitability of the pilot test.

\subsection{Face Validity}

In order to make sure the face validity of the research tool, the questionnaire items were submitted to a number of specialized academic People to comment on the items of the questionnaire. Consequently, a few of the items were modified based on their comments, suggestions, and recommendations.

Paltridge (2012) explains that validity is the accuracy of the study which aims at proving the trustworthiness of the research method, which is supported by many other researchers in the same field to prove the speculation of the investigation. 


\subsection{Ethical Considerations}

The strategy of the researcher is that nobody has been obliged to take part in this research with regards to confirming a consent form while collecting the data. Barker et al (2001) argue that ethics refers to self-care of individuals in a community; self is the most centralized ethic in one's life which is concerned everyday with the life of others.

\section{Research Analysis Methods}

The current study includes a quantitative research method that involved a questionnaire among Pshdar people and the collected data was entered into the updated version 20 of SPSS program so as to be analysed in accordance with the recent academic standard.

\subsection{Results}

This section highlights the quantitative data which has been gathered and analyzed on the bases of ordinary individual participants.

\section{Results of Social Values:}

\begin{tabular}{|cc|}
\hline \multicolumn{2}{|c|}{ Age } \\
Scale & Frequency \\
$18-35$ & 81 \\
$36-80$ & 81 \\
total & 162 \\
\hline & Gender \\
\hline Scale & Frequency \\
male & 124 \\
female & 38 \\
total & 162 \\
\hline Marital Status \\
\hline
\end{tabular}




\begin{tabular}{|c|c|c|}
\hline Scale & \multicolumn{2}{|c|}{ Frequency } \\
\hline Single & \multicolumn{2}{|l|}{46} \\
\hline Married & \multicolumn{2}{|c|}{116} \\
\hline total & \multicolumn{2}{|l|}{162} \\
\hline \multicolumn{3}{|c|}{ Social Classes } \\
\hline Scale & \multicolumn{2}{|c|}{ Frequency } \\
\hline \multicolumn{3}{|c|}{ Lower Class } \\
\hline \multicolumn{3}{|c|}{ Medium Class } \\
\hline \multicolumn{3}{|c|}{ High Class } \\
\hline \multicolumn{3}{|l|}{ Total } \\
\hline \multicolumn{3}{|c|}{ Economic Status } \\
\hline Scale & \multicolumn{2}{|c|}{ Frequency } \\
\hline Rich & \multicolumn{2}{|l|}{5} \\
\hline Medium & \multicolumn{2}{|c|}{141} \\
\hline Poor & \multicolumn{2}{|l|}{16} \\
\hline Total & \multicolumn{2}{|c|}{162} \\
\hline & $\begin{array}{l}\text { cation } \\
\text { rgrou }\end{array}$ & \\
\hline
\end{tabular}




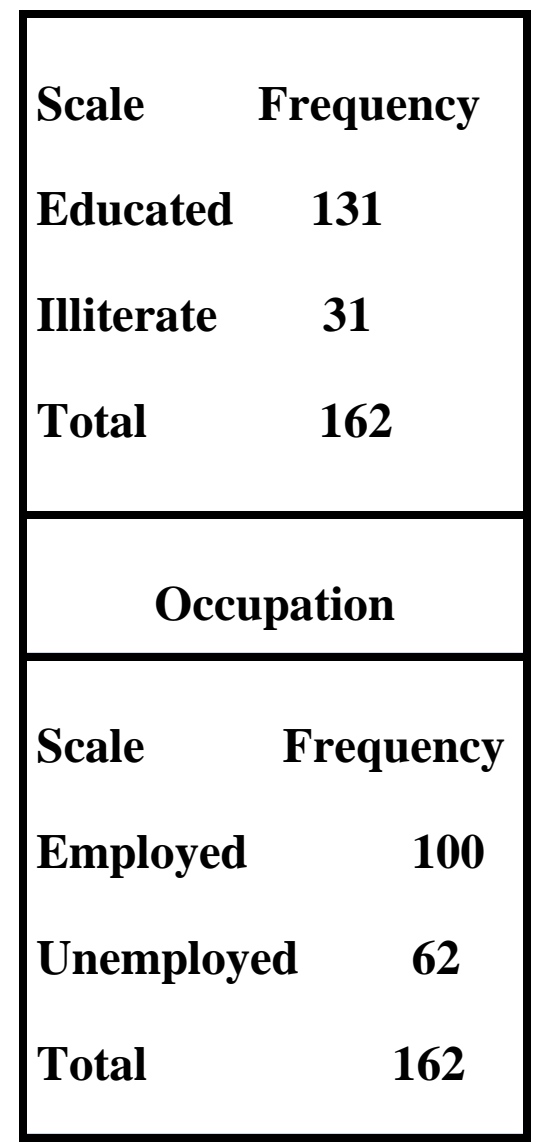

The age of the participants ranged from 18-35, and 36-80 in the frequency of 81 by 81 which becomes 162 is the number of the people who took part in the study. On the other hand, the male are 124, and the females are 38. The ratio of the people who took part in the study, according to the gender classification; however, the number of the males are much more than the number of the females, due to the restriction of the community taking part in this kind of survey study. Unfortunately, in this specific area the females were not allowed to contribute to this kind of studies. According to the marital status of the people, the married people are 116, while the single people are 46, which they contributed to the study. In accordance with social classes ordinary people can be classified into three different types, which are 20 lower class people, 131 medium class people, and 11 high class people that contributed to the study. Nevertheless, Economic status range of people can also be divided into three different categories, namely 5 rich people, 141 medium people, and 16 poor people, who took part in this research. Finally, according to the occupation of the people, 100 employed people, and 62 unemployed people have been taken part in this research. 
The analyzed data of the questionnaire.

\begin{tabular}{|c|c|c|c|}
\hline Items & Participants & Mean & $\begin{array}{l}\text { Standard } \\
\text { deviation }\end{array}$ \\
\hline 1. Ahmed asks you to give him some money & 162 & 3.46 & 1.61 \\
\hline $\begin{array}{l}\text { 2. Azad wants you to go with him to gain } \\
\text { charity. }\end{array}$ & 162 & 4.19 & 1.12 \\
\hline $\begin{array}{l}\text { 3. Muhammad says what are you doing this afternoon? } \\
\text { What do you think if we help Allan? }\end{array}$ & 162 & 4.12 & 1.57 \\
\hline $\begin{array}{l}\text { 4. Hawraz invites you for dinner, you will have eaten } \\
\text { well there, and Ako is with you, Hawraz tells you when } \\
\text { do you re invite us for a meal? }\end{array}$ & 162 & 4.48 & 1.02 \\
\hline $\begin{array}{l}\text { 5. Dlshad is a homeless person; you know that, } \\
\text { someone asks you why do not you take Dlshad to your } \\
\text { home? }\end{array}$ & 162 & 3.96 & 1.34 \\
\hline $\begin{array}{l}\text { 6. Bana's daughter needs someone to study in } \\
\text { mathematics urgently; the person is a student, if Bana } \\
\text { asks you to guide her student, while you also have an } \\
\text { important test do you do it }\end{array}$ & 162 & 2.70 & 1.79 \\
\hline $\begin{array}{l}\text { 7. Azad is going to help poor people as a volunteer from } \\
\text { now. Are you doing so? }\end{array}$ & 162 & 4.67 & 0.70 \\
\hline $\begin{array}{l}\text { 8. There is a religious charity for orphans; you are as a } \\
\text { Muslim, do you want to take part of this charity? }\end{array}$ & 162 & 4.70 & 0.65 \\
\hline $\begin{array}{l}\text { 9. Ako knows a widow who has some orphans; you are } \\
\text { one of those who God gifted you too much. Do you } \\
\text { want to help them by your money to buy a house? }\end{array}$ & 162 & 4.45 & 1.10 \\
\hline $\begin{array}{l}\text { 10. A woman wants you help her, she knows you, you } \\
\text { can do that. Are you ready to help her because of the } \\
\text { requester is a female? }\end{array}$ & 162 & 2.15 & 0.69 \\
\hline
\end{tabular}

According to the first item, the mean of this output is 3.46, which shows a positive acknowledgement. It has been noted that some of the individuals of this limited area minimize themselves to others through this maxim since they are ready to give. Moreover, he mean of the second item is 4.19 , which shows a positive acknowledgement among the people who use 
language in context by using this maxim. In accordance with the third item the mean of this output is 4.12 , which shows a positive acknowledgement that enhances the level of cooperative working among individuals in this limited area which are in a high value of society accounted for, and mingling with the most common maxim of pragmatic politeness associated. In other words, the mean output of the fourth item is 4.48 which shows a positive acknowledgement. The responses have proved that the term of hospitality in the sense of generosity is a high value among individuals of this specific area, while performing language in a different social situation that is minimizing self and maximizing to others. However, this item has impositive impact on the listener, which holds face threatening act. Meanwhile most of the people are ready to agree to the request. Nevertheless, the mean of the fifth item is 3.96 which shows a positive acknowledgement. Through observing that survey most of responses undertake the religious responsibility, and the language user performs well according to five pillars of Islam religious system. More importantly, religion puts everyone in front of the responsibility. According to the sixth item the output mean is 2.70 which can be regarded as a low positive value to educated people, whereas they should have been more ready to help Bana's daughter, in regard to gender-specific as appeared in this item. The responses of the participants show under the influence of gender differences. On the other hand, the mean of this output of the seventh item is 4.67 which shows a high positive value. It is noted that all kinds of people, according to the social values used in this study in this limited area are known by cooperativeness with whom, who are in need. Moreover, the mean of the eighth item is 4.70 it can be noted as a high positive value for participants while performing language in a context. According to the responses of the people with regarding to Islam as their religion therefore their readiness is very high to do the charity, because Muslims have to share their possessiveness. In accordance with the ninth item the mean is 4.45 which can be observed as a positive acknowledgement in the context through using linguistic knowledge by a language user. This utterance is regarded to minimize self to others that means the majority of the participants are ready to give for others. It seems that those people who know how to help poor ones when they are in need? Whereas, the mean of the tenth item is 2.15 which can be noted as a low positive acknowledgement, however the participants' responses are under the influence of gender-specific again, thus their readiness to give reduced because people mostly manage to avoid this kind of request. On the other hand, social distance is considered to be another factor. Consequently, most of the responses take care of this directiveness, because partially they are not ready to help her. It is worth mentioning in the questionnaire for those who do not know English language the researcher manages to add Kurdish language for participants, as in( appendix A) shown. 


\subsection{The results of items of the questionnaire:}

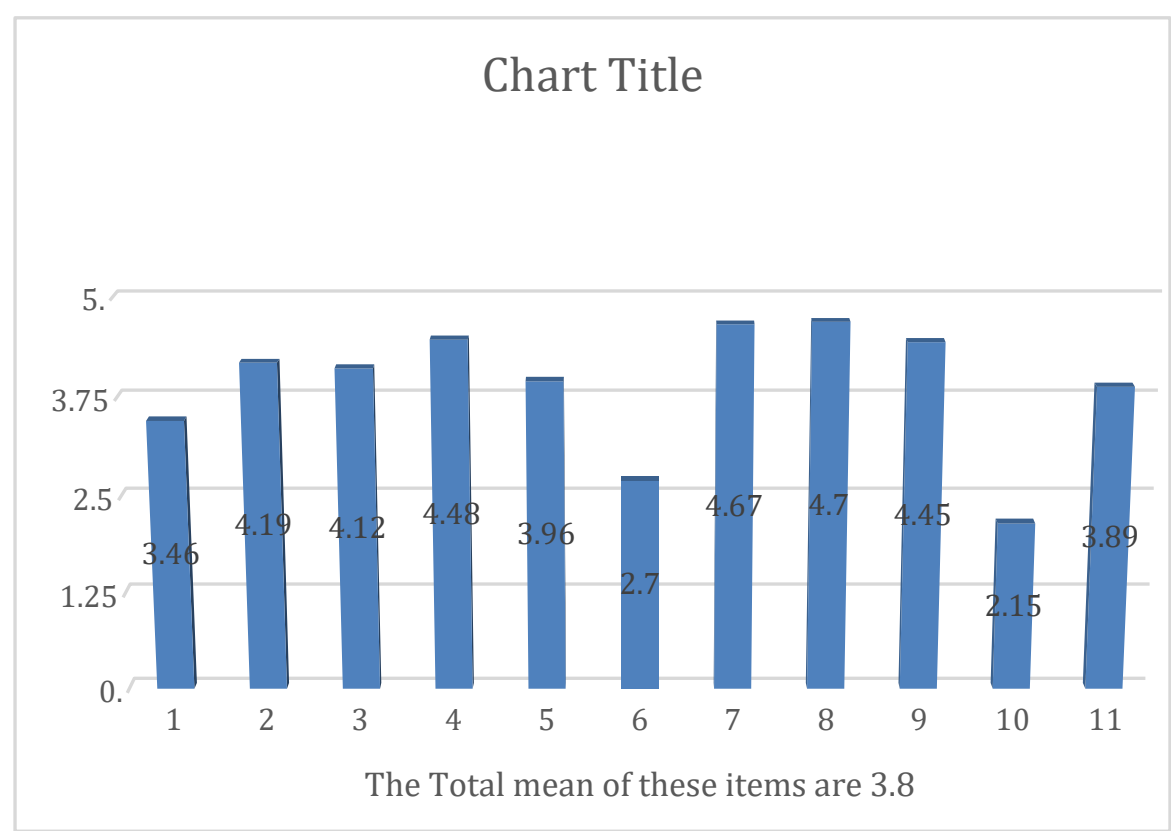

According to the overall results of the study, the total mean of all items is 3.88 , which shows a positive acknowledgement. It is important to bear in mind that the results of the items have some weaknesses and strengths points as follows.

According to high positive value of item eight, it shows that the strongest item of the language users in the study, which the research question of the study got the answer by this item, in which religion has a great role among individuals. Whereas, the low positive acknowledgement of the item ten which shows the weakest item of the language users in the study, because the language performer under the influence of social value of gender responded. On the other hand, a high positive value of item seven shows a strong point, because it could be noted the kindness of the people in cooperation with those in need. Meanwhile, a low positive value of education in this limited area shows a weak point, because the educated people are expected to be more generous than the result of the mean of this item output. Nevertheless, a positive acknowledgement of item four shows strong points again, because the language users prove the generosity and hospitality of the people, which appeared in the output of the item. However, a positive acknowledgement of item one shows a weak point, therefore from the language users are expecting more generosity than the result looked. In accordance with observing positive acknowledgement in the context of item nine, which shows a strong point in the study, due to the mean output of the item majority of the participants are ready to give for others'. While a positive acknowledgement of item five shows a weaker point than the item nine, owning to observing a believed people are expected to be more responsible than the result of the mean of the item shown. Finally, the positive acknowledgement of the item two shows a 
strong point, though cooperativeness among participants obviously has been noted by using language in context in this item. Contrastively, a positive acknowledgement of item three shows a weak point since the enhancement of the level of cooperation working among individuals in a high value of society is very low.

\subsubsection{Conclusions of the study}

Based on the analyzed data and discussed interview data, the following conclusions have been drawn, which were noted in general over the Kurdish culture sociopragmatically perspective.

1- Social values such as religion, financial status, and gender

had a great role in acting generously, nonetheless, the fact that women were more generous than men in some specific.

2- Occupation among the social values had no effectively the enactment of generosity maxim while language was used.

3- Social distance had also affected the participants to show generosity.

4- The verbal message of generosity had an effect on social life.

5- Pshdaryan had a high level of pragmatic language use according to this maxim used in the study.

6- Individuals have wide correlation with around through showing generosity between each other in the Kurdish culture.

7- Social values did not affect the pragmatic maxim of generosity as compared to social norms in Kurdish society.

\subsubsection{Recommendation for further study}

According to the research conclusion, the researcher recommends the following:

1- It is highly recommended that other politeness principle maxims are to be tested in Kurdish culture to know the level of the maxims practically.

2- That will be great if other places in Iraqi Kurdistan-Region will be compared, to know the level of pragmatic language usage among individuals in a specific area. 
3- It is great to guide other researchers to do more research over pragmatic language usage by using different methods than in any topic which they would like to do except these researches have been done before.

\section{Appendix A}

\begin{tabular}{|c|c|c|c|}
\hline Items & Participants & Mean & $\begin{array}{l}\text { Standard } \\
\text { deviation }\end{array}$ \\
\hline 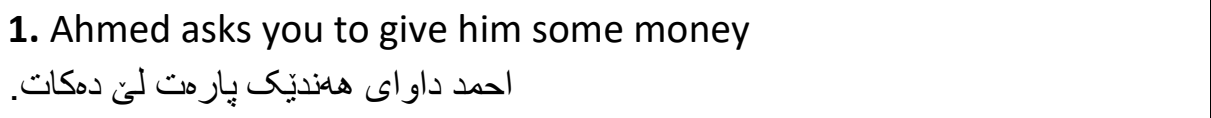 & 162 & 3.46 & 1.61 \\
\hline 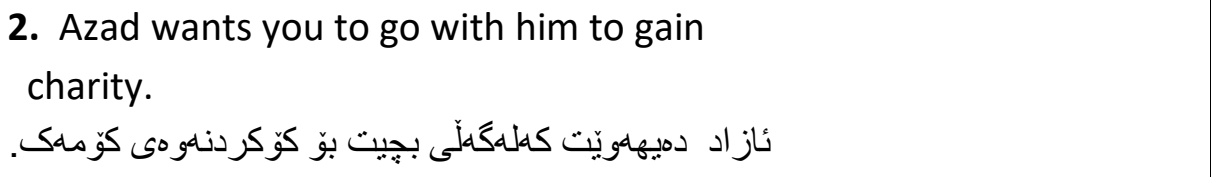 & 162 & 4.19 & 1.12 \\
\hline 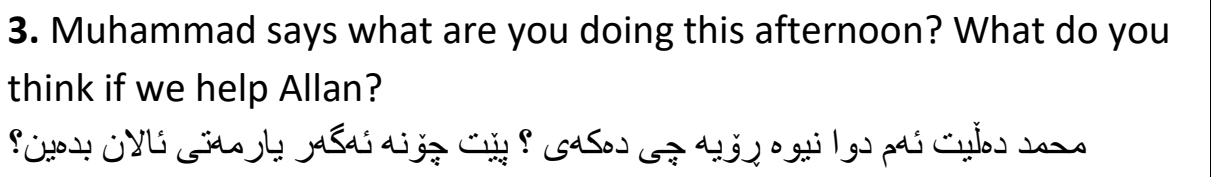 & 162 & 4.12 & 1.57 \\
\hline 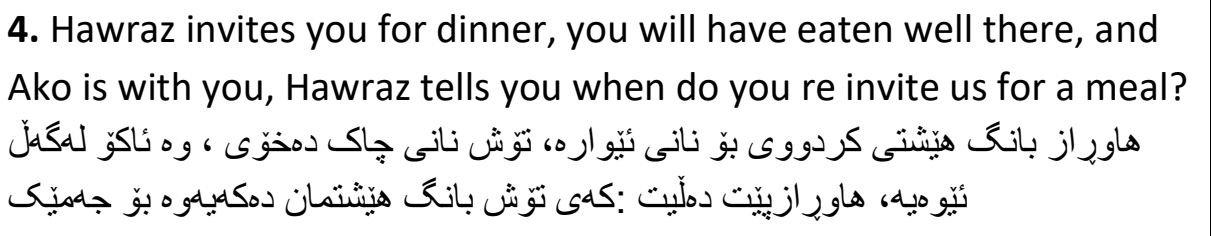 & 162 & 4.48 & 1.02 \\
\hline 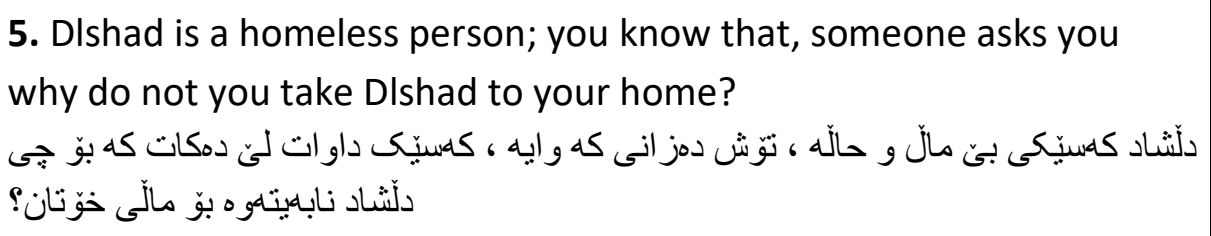 & 162 & 3.96 & 1.34 \\
\hline 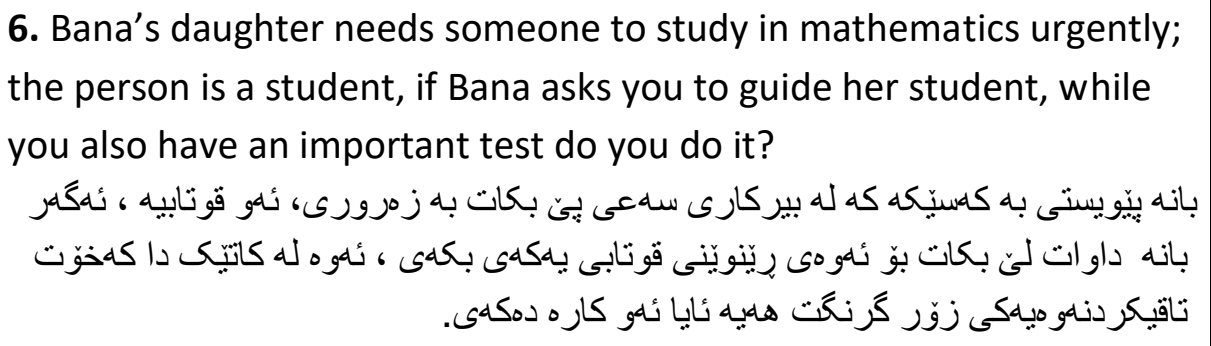 & 162 & 2.70 & 1.79 \\
\hline 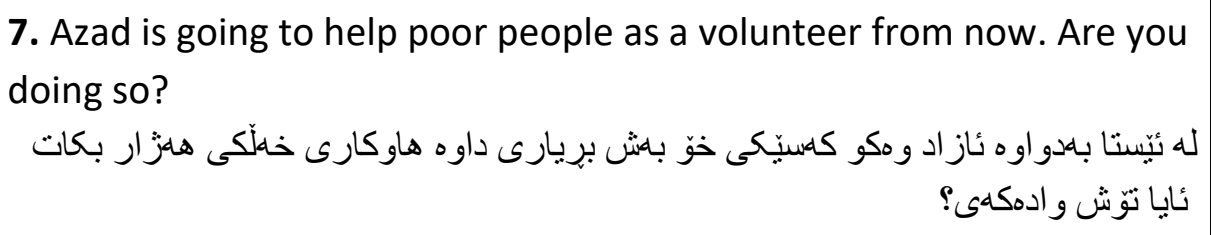 & 162 & 4.67 & 0.70 \\
\hline
\end{tabular}




\begin{tabular}{|c|c|c|c|}
\hline 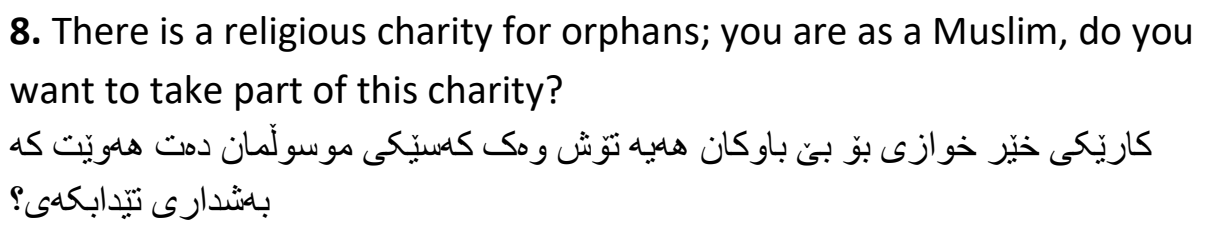 & 162 & 4.70 & 0.65 \\
\hline 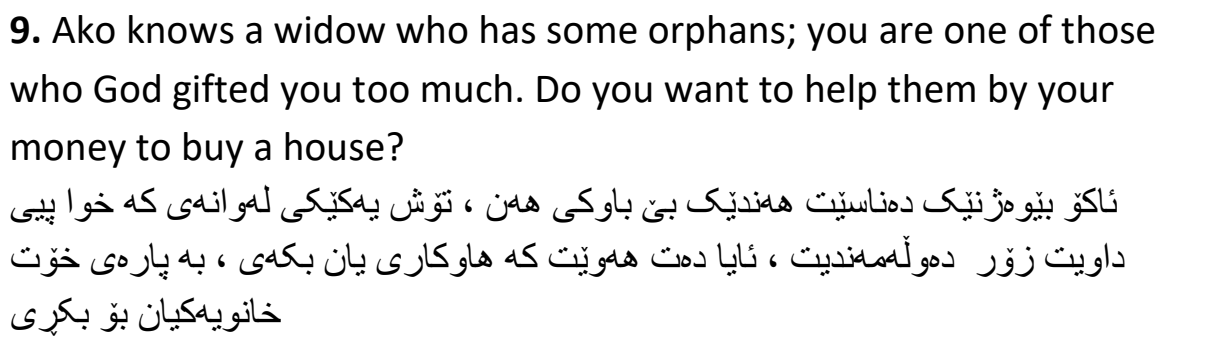 & 162 & 4.45 & 1.10 \\
\hline 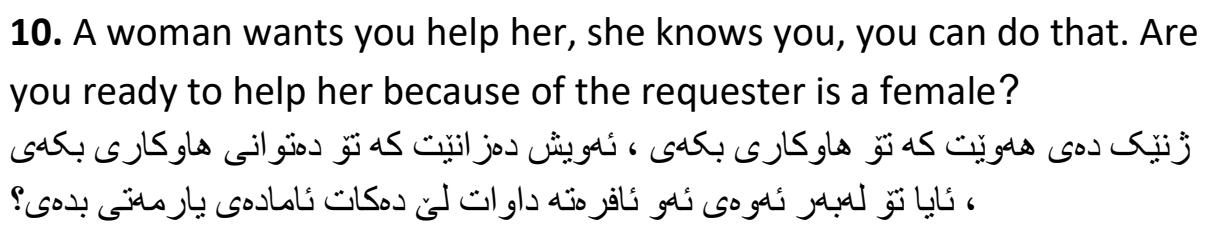 & 162 & 2.15 & 0.69 \\
\hline
\end{tabular}




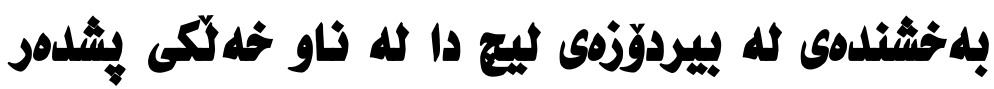

ابراهيه محمود ابراهيب

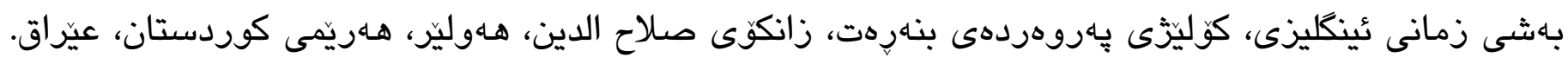
ئيمهيل: imirbr1@gmail.com

\section{سلام ناوخوَش بكر}

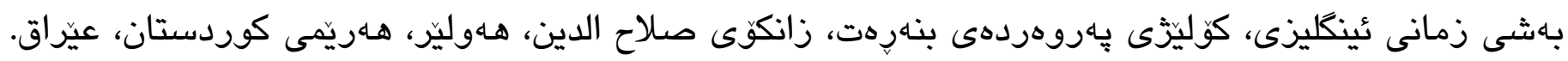
salam.bakir@su.edu.krd ئيمهيل

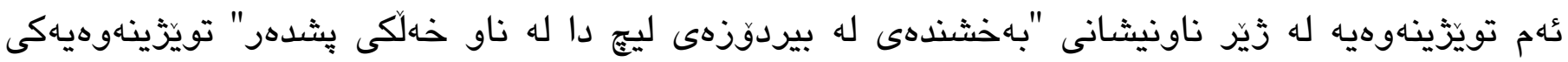

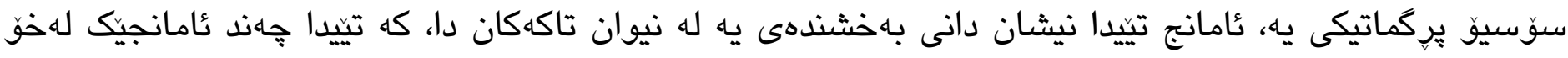

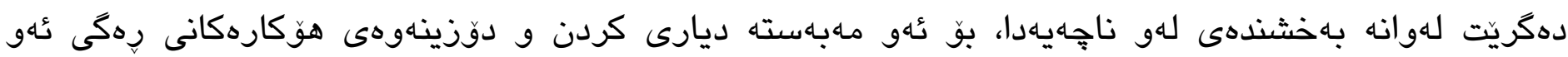
بهخشندهيه لهناو دانيشتوانهكدا.لهبهر ئهوهى بهخشندهى زيادكردنه له بهرانبهر و كهم كردنهوهيه له قسهكهر، وه

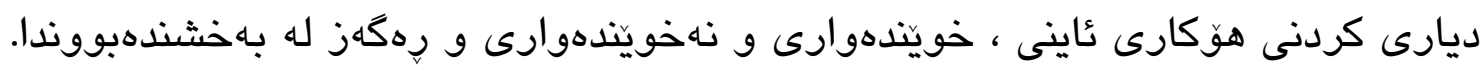

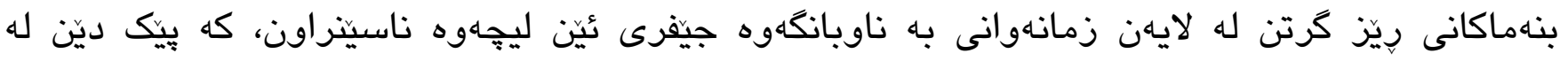

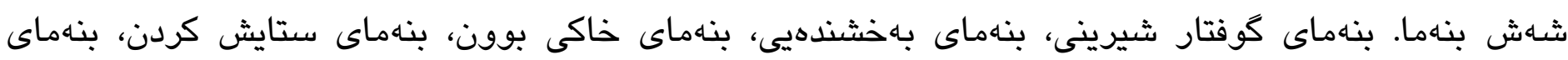
رازييوون، وه بنهماى هاوسوزى.

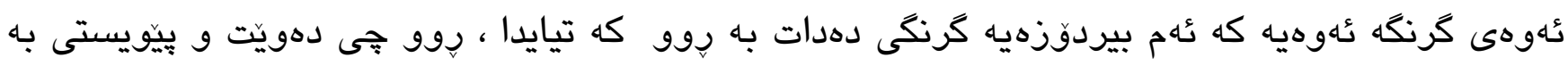

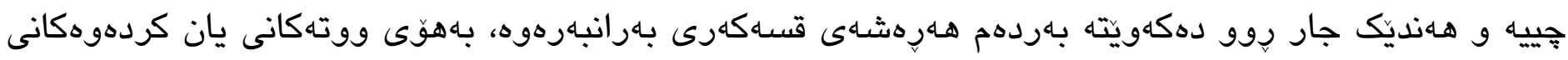

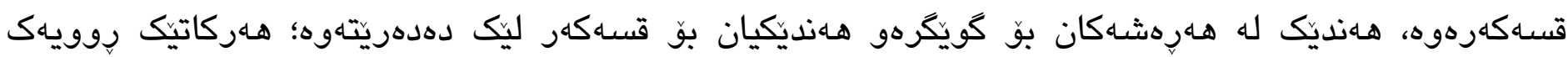

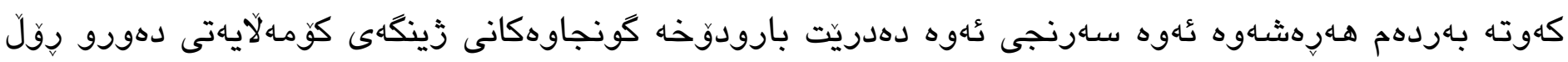
دهكيزنٍن. 


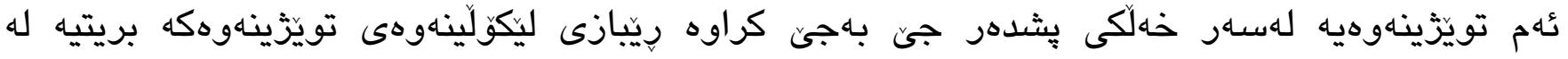

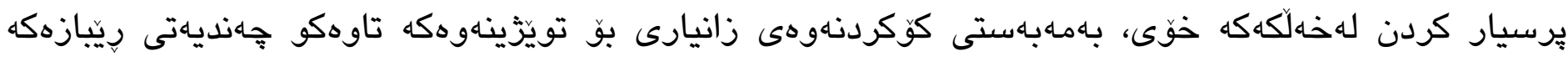

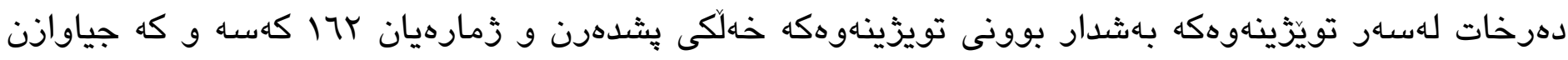

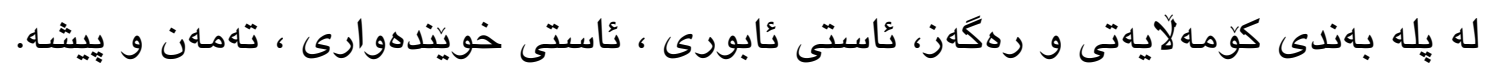
له دهر ئهنجامى تويّزينهوهكها تئوه دهركهوتووه كه بنهماى بهخشندهى هوكارى سـهرهيه له هـردوو

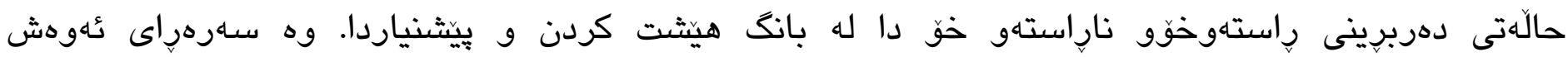
تويّزينهوهيهكه ئهوه دهردهخات كه ثاستى تيّهووى ريّز له نيّوان خهلكهكها له ئاستيكى بهرزدايه به بـراورد بـه راستهو خُو و ناراستهو خوّى هـهر كردهو وتهيهكى بهشدار بووان.

له كوتايدا رِينويِنى ئهوه دهكريّ،كه بنهماكانى ترى ريّز كرتن تاقيبكرينهوه له كهلتورى كورديدا به مـابهاستى زانينى عاستى كردار يانهى بنهاكان.

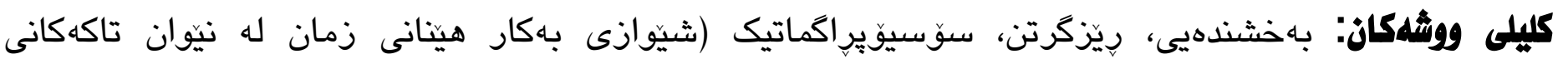

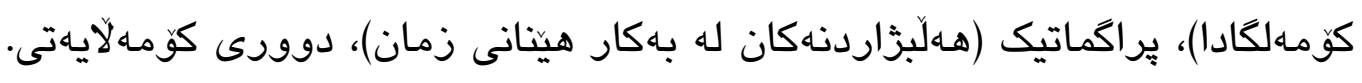




\section{References:}

Allan, K. \& Jaszczolt, K.M., 2012. The Cambridge Handbook of Pragmatics. 1st ed. Cambridge: Cambridge. University press

Bakir, S.N., 2015. Female and Culture. 1st ed. Erbil: Renwen.

Bargiela-Chiappini, F. \& Kadar, D.Z., 2011. Politeness across cultures. Hampshire: Palgrave Macmillan.

Barker, C. \& Galasinski, D., 2001. Cultural Studies and Discourse Analysis. 1st ed. London: Sage.

Bezu, \& Holden, T., 2015. Generosity and Sharing among villagers: Do women give more?. Journal of Behavioural and Experimental Economics. Elsevier, 57, pp.103-11.

Brown, K., Barber , A. \& Stainton, R.J., 2010. Concise Encyclopaedia, Philosophy of Language and Linguistics. Oxford: Elsevier.

Brown, P. \& Levinson, C., 1987. Some Universals in Language Usage: Studies inInteractional Sociolinguistics 4. 2nd ed. Cambridge: Cambridge University Press.

Crystal, D., 2007. How Language Works. London: Penguin.

Eelen, G., 2001. A Critical of Politeness Theory. Manchester, UK: St. Jorem Publishing Press.

Froding, B., 2013. Virtue Ethics of Human Enhancement. London: Springer.

Geyer, N., 2008. Discourse and Politeness, Ambivalent Face in Japanese. London, UK: Continuum.

Grundy, P., 2013. Doing Pragmatics. 3rd ed. New York: Routledge.

Lakoff, R.T., 2004. Language and women's place, Text and commentaries. OxfordNew York.

LoCastro, V., 2012. Pragmatic for Language Educators: A Sociolinguistic Perspective. 1st ed. London: Routledge Taylor Frances. 
Leech, G.N., 1983. Principles of Pragmatics. 1st ed. London: Longman.

Leech, N., 2014. The Pragmatic of politeness. New York, UK: Oxford. University press

Mark, W. \& Thrones, , 2001. Research made real, A guide for students. Oxford : Oxford. University press

Meyer, C.F., 2009. Introduction English Linguistics. 1st ed. Cambridge,: Cambridge. University press

Paltridge, B., 2012. Discourse Analysis An Introduction. 2nd ed. London: Bloomsbury.

Rasul, R.K., 2018. Qalat-Dizah Town. 1st ed. Sulaimaniyah: Zana.

Reimer, N., 2010. Introducing Semantics. New York: Cambridge. University press

Robson, C. \& McCartan, K., 2011. Real World Research. 4th ed. John Wiley.

Tobler, P., 2020. Generosity Reward is a Happier You. Science Direct, 65(4), p.304.

Watts, R.J., 2003. Politeness, Key Topics in Sociolinguistics. 1st ed. New York, UK: Cambridge university press

Yule, G., 1996. Pragmatics. Oxford: Oxford university press 